\title{
Phenotypic characterization of native pig in Romblon province, Philippines
}

\author{
Ken N Falculan \\ Romblon State University, College of Agriculture \\ Odiongan, Romblon, 5505, Philippines \\ ken.falculan@1spu.edu.ph
}

\begin{abstract}
This study was conducted to determine the phenotypic characteristics of native pigs in the province of Romblon. Specifically, it identifies the phenotypic characteristics, morphometric diversity, and effective population size of the native pigs. This study used the descriptive design. The data gathered were statistically analysed using frequency/percentage, mean, regression analysis and correlation. From the analysis and interpretation conducted it was found out that: majority of the snout were long and thin; the head profile was straight; most of the ear type was droopy; the ear orientation were projected forward; have straight hair; the coat color pattern were plain; the coat color was black; the skin were smooth; the tail were straight and the backline was straight except for gilt which is swaybacked. The Shannon Weiner Diversity Index on the phenotypic characteristics of native pigs in the province of Romblon was observed evenly distributed. There is significant relationship observe on the morphometric diversity of native pigs.

Keywords: Tablas, Sibuyan, Romblon, native pig, phenotypic, morphometric
\end{abstract}

\section{Introduction}

Agriculture is the backbone of the Philippine economy and the prime mover of national development. The economic means of livelihood of more than half of the population is agriculture and it is a key factor in the country's pursuit to become a newly industrialized country status. Reflecting the economic state of the country, the agriculture sector accounts for more than half of the nation's population who are locked in absolute poverty.

The economic importance of native animals largely depends on their unique phenotypic and genetic characteristics that make them fit into the environment and conditions of small-scale farms. The native animal's importance is also influenced by its ability to produce products with attributes that are preferred and paid a premium price by consumers. The success in the conservation and utilization of native animals largely depend on the identification and development of these unique characteristics. Native animals and other newly domesticated animal have the ability to survive and reproduce under natural environments with minimal material and technological inputs, they perceived neutralceutical value, and are highly preferred for their taste, flavor and texture of meat. Due to the native animals' adaptation characteristics, cost to produce them is generally lower compared to their hybrid counterpart. The second largest contributor to the country's agriculture economy is the swine industry. The preference of Filipino consumers for fresh warm or chilled pork over frozen pork gives the local industry market assurance of its products. However, the importation of low-priced beef, buffalo meat and poultry meat may create a shift in consumption from pork to these cheaper alternatives.

Backyard swine raisers continue to be an important form of livestock production in many low income countries. In the Philippines over 80 percent of all pigs are kept in small scale herds. 
According to Romblon's Provincial Agricultural Profile (2016), the small scale livestock and poultry production is viable industry in the province since the government supports the farmers to venture into this enterprise.

The province of Romblon is part of the quest which has a population of 292,781 people with a density of 190 inhabitants (PSA Report, 2015). Whose economy is very much dependent on agriculture in which livestock development and poultry production is a viable small scale enterprise for farmers in the province (PSA, 2013). The native pigs of Romblon were considered endangered while other having population size of less than 100 head breeding females were considered under critical status (Sulabo, 2009).

Though indigenous native pigs is important genetic resources and are currently under threat from extinction, there is no well-integrated information system in the province to account them. To achieve the conservation and preservation of genetic resources, efforts are required from a variety of institutions with the cooperation of local government units, academe, breed supply companies, farms and farmers to have accurate information on indigenous farm animal genetic resources including information on the population size, distribution and phenotype to possibly grasp the critical status of native pigs in the province and to take possible measures to prevent extinction of the species.

\section{Methodology}

The descriptive method of research was used because; it describes and interprets what is. It concerns with conditions of relationships that exist; practices that prevail; beliefs, processes that are going on; effects that are being felt, or trends that are developing (Calderon and Gonzales, 1993).

\section{Subject of the study}

The phenotypic characteristics, population structure and phenotypic diversity of native pigs was identified.

\section{Sampling Technique}

The non-scientific or non-probability sampling method was used. This was employed because in nonprobability sampling, not all of the individuals in a population are given equal chance of being included in the sample. Hence, the sample is selected based on subjectivity. Likewise, this method was used to characterize the phenotypic characteristics, population structure, and the phenotypic diversity of native pigs.

\section{Materials and Instrument}

The material and instrument used are the following: measuring tape was used for linear body measurements such as body length, heart girth and tail length; meter stick was preferable to tapes for measuring vertical heights; weighing scale (spring balance and hanging canvas sling, a General Master Hanging Scale Japan Technology 100kg/220lbs) was used in measuring the body weights of the native pigs; digital camera (Model Nikon D3100 AFS DX NIKKOR 18-55 mm f/3.5-5.6G VR) which are needed to capture images of animals and can also be used to record subjective qualitative data (e.g. shape, appearance and color) for comparison and standardization; Global Positioning System (GPS) Garmin eTrex 30 model to record geographical distance and elevation.

\section{Procedure}

The procedures that were used to determine the phenotypic characterization and population structure of native pigs were as follows:

- Conduct survey and identification of native pigs according to their phenotypes and population structure;

- Weighing and measuring of sample data;

- Capturing images;

- Recording of data gathered;

- Analyzed the data gathered 


\section{Data Gathering Procedure}

The main instrument in gathering data was the questionnaire. The instrument was distributed to the respondents to answer the questions followed by unstructured interview. Retrieval of questionnaire was done immediately to minimize the loss of data. Upon retrieval of the questionnaire from the respondents the data that were gathered were the phenotypic characteristics, population structure and phenotypic diversity of native pigs through the use of weighing scale, measurements and capturing images. Recording of data were done immediately.

\section{Data Processing and Statistical Procedures}

The data that was gathered from the respondents and experimental procedure was statistically analyzed using the Special Program for Social Sciences (SPSS) version 2.0. The statistical tools employed in analyzing the data were as follows: frequency count/percentage was the statistical tools used to identify the phenotypic characteristics of the native pigs in relation to sex, hair, tusks, snout, coat color pattern, coat color type, head profile, ear type, ear orientation, skin, tail type, backline, body weight and body size for adult, boar and sow; the phenotypic diversity and equitability of distribution in each group of native pigs; the population structure of native in relation to effective population size, and phenotypic diversity using Shannon- Weiner Diversity Index to determine the evenness of the phenotypic characteristics of native pigs in the province of Romblon. The Shannon Weiner Diversity Index $(\mathrm{H})$ was used to characterize species diversity which provide important information about the rarity and commonness of species in a community. To calculate the Shannon Weiner Diversity Index, the following formula was employed:

$$
\left.\mathrm{H}=\sum \underset{\mathrm{i}=1}{\mathrm{~s}} \operatorname{Pi} * \ln \mathrm{Pi}\right)
$$

Where: $\mathrm{H}=$ the Shannon Weiner Diversity Index; $\mathrm{Pi}=$ fraction of the entire population made up of species I; $\mathrm{S}=$ numbers of species encountered; $\sum=$ sum from species 1 to species $\mathrm{S}$. It must be noted that the power to which the base e $(\mathrm{e}=2.718281828 \ldots . . .$.$) must be raised to obtain a number is called$ the natural logarithm (ln) of the number. To calculate the index, divide the number of individuals of species \#1 found in sample by the total number of individuals of all species. This is Pi; multiply the fraction by its natural $\log (\mathrm{P} 1 * \ln \mathrm{P} 1)$; repeat this for all of the different species. The last species is species "s"; sum all the - $(\mathrm{Pi} * \ln \mathrm{Pi})$ products to get the value of $\mathrm{H}$.

\section{Result and Discussion}

Phenotypic diversity and the population structure of native pigs in the province of Romblon.

It was indicated on Table 14 that no tusks were found among the native pigs located in the province of Romblon; majority of the snout of boar (7) and sow (10) were long and thin; the head profile were straight; most of the ear type were droopy; and majority of the ear orientation of boar (9), sow (17), and gilts (6) were projected forwards except for the 2 piglets which was projected upwards. Most of the similarities in body morphology and phenotype between native pigs could be due to gene flow which still exists in rural extensive management system (Subalini et al., 2010). The measurements of head in native pig populations showed no difference carried a straight tail. Similarities in head measurements and head shape among native pig were reported by Sahaayaruban et al. (1983), indicating that distinct features of the native pig, such as tapering face and long snout could be observed also in native pigs. 
Table 14. Distribution of Romblon native pigs according to their phenotypic characteristics (head portion).

\begin{tabular}{|c|c|c|c|c|c|c|c|c|c|c|c|}
\hline \multirow[t]{2}{*}{ Indicators } & \multicolumn{4}{|c|}{ Tablas Island } & \multicolumn{3}{|c|}{$\underline{\text { Sibuyan Island }}$} & \multicolumn{4}{|c|}{ Romblon Province } \\
\hline & Boar & Sow & Gilt & $\begin{array}{c}\text { Pigle } \\
\mathrm{t}\end{array}$ & Boar & Sow & Gilt & Boar & Sow & Gilt & $\begin{array}{c}\text { Pigle } \\
\mathrm{t}\end{array}$ \\
\hline \multicolumn{12}{|l|}{ Tusks: } \\
\hline Present & 1 & - & - & - & - & - & - & 1 & - & - & - \\
\hline Absent & 7 & 14 & 4 & 2 & 2 & 6 & 3 & 9 & 20 & 7 & 2 \\
\hline \multicolumn{12}{|l|}{ Snout: } \\
\hline $\begin{array}{l}\text { Long } \\
\text { and } \\
\text { thin }\end{array}$ & 6 & 10 & 1 & - & 1 & - & 2 & 7 & 10 & 3 & 1 \\
\hline $\begin{array}{c}\text { Short } \\
\text { and }\end{array}$ & 2 & 4 & 3 & 2 & 1 & 6 & 1 & 3 & 10 & 4 & 1 \\
\hline \multicolumn{12}{|l|}{ Cylindrical } \\
\hline \multicolumn{12}{|l|}{ Head profile: } \\
\hline Concave & 2 & 1 & - & - & - & 5 & - & 2 & 6 & - & - \\
\hline Straight & 6 & 13 & 3 & 2 & 2 & 1 & 3 & 8 & 14 & 6 & 2 \\
\hline Convex & - & - & 1 & - & - & - & - & - & - & 1 & - \\
\hline \multicolumn{12}{|l|}{ Ear type: } \\
\hline $\begin{array}{c}\text { Droopy } \\
\text { (pendulous) }\end{array}$ & 8 & 10 & 3 & - & 1 & 5 & 3 & 9 & 15 & 6 & 1 \\
\hline $\begin{array}{l}\text { Semi- } \\
\text { Loop }\end{array}$ & - & - & - & - & - & 1 & - & - & 1 & - & - \\
\hline Loop & - & - & 1 & - & - & - & - & - & - & 1 & - \\
\hline $\begin{array}{l}\text { Prick } \\
\text { (erect) }\end{array}$ & - & 4 & - & 2 & 1 & - & - & 1 & 4 & - & 1 \\
\hline \multicolumn{12}{|c|}{ Ear orientation: } \\
\hline $\begin{array}{l}\text { Project } \\
\text { forwards }\end{array}$ & 8 & 11 & 3 & - & 1 & 6 & 3 & 9 & 17 & 6 & - \\
\hline Backwards & - & - & 1 & - & - & - & - & - & - & 1 & - \\
\hline Upwards & - & 3 & - & 2 & 1 & - & - & 1 & 3 & - & 2 \\
\hline
\end{tabular}

It was indicated on Table 15 on the body portion of native pigs, that majority of the native pigs have straight hair; the coat color pattern for boar (9), sow (20), gilts (5), and 1 piglet were plain except for 1 piglet was patchy; majority of the coat color type were black; the skin were smooth; the tail were straight; and the backline of boars (7) and sows (11) were straight except for gilts (4) which were swaybacked. Unlike descriptive traits, body measurements, which are quantitative characters, are influenced by both genotype and environment. Therefore, the variation in body measurements may be attributed partly to the variation in availability of feed resources and rural situations. This was confirmed by Jones (1998), who reported that the feed resources in forest area has high energy content than the refuse available in villages for pigs reared under semi intensive system. Also, the directional force in selective breeding could be another factor that contributed in making a difference in body size. 
Table 15. Distribution of Romblon native pigs according to their phenotypic characteristics (body portion).

\begin{tabular}{|c|c|c|c|c|c|c|c|c|c|c|}
\hline \multirow[t]{2}{*}{ Indicators } & \multicolumn{3}{|l|}{ Tablas Island } & \multicolumn{3}{|c|}{ Sibuyan Island } & \multicolumn{4}{|c|}{ Romblon Province } \\
\hline & Boar Sow & $\begin{array}{l}\text { Gil } \\
\mathrm{t}\end{array}$ & $\begin{array}{l}\text { Pigle } \\
\mathrm{t}\end{array}$ & Boar & Sow & Gilt & Boar & Sow & Gilt & $\begin{array}{l}\text { Pigle } \\
\mathrm{t}\end{array}$ \\
\hline
\end{tabular}

Hair:

$\begin{array}{llllllllllll}\text { Curly } & 1 & 2 & - & 1 & - & - & 1 & 1 & 2 & - & 1 \\ \text { Straight } & 5 & 10 & 3 & 1 & 1 & 3 & 2 & 6 & 13 & 5 & 1 \\ \text { Short } & 2 & 1 & 1 & - & - & 2 & - & 2 & 3 & 1 & - \\ \text { Long } & - & 1 & - & - & - & 1 & - & - & 2 & - & - \\ \text { Dense } & - & - & - & - & 1 & - & - & 1 & - & - & -\end{array}$

Coat color pattern:

$\begin{array}{llllllllllll}\text { Plain } & 7 & 14 & 3 & 1 & 2 & 6 & 2 & 9 & 20 & 5 & 1 \\ \text { Patchy } & - & - & - & 1 & - & - & 1 & - & - & 1 & 1 \\ \text { Spotted } & 1 & - & 1 & - & - & - & - & 1 & - & 1 & -\end{array}$

Coat color type:

$\begin{array}{llllllllllll}\text { White } & 2 & - & 1 & - & - & - & - & 2 & - & 1 & - \\ \text { Black } & 6 & 13 & 2 & 1 & 2 & 6 & 2 & 8 & 19 & 4 & 1 \\ \text { Dark red } & - & 1 & 1 & - & - & - & - & - & 1 & 1 & - \\ \text { Gray } & - & - & - & - & - & - & 1 & - & - & 1 & - \\ \text { Brown } & - & - & - & 1 & - & - & - & - & - & - & 1 \\ \text { Gray } & & & & & & & & & & & \end{array}$

Skin:

$\begin{array}{llllllllllll}\text { Smooth } & 8 & 14 & 3 & 2 & 2 & 4 & 3 & 10 & 18 & 6 & 2 \\ \text { Wrinkled } & - & - & 1 & - & - & 2 & - & - & 2 & 1 & -\end{array}$

Tail type:

$\begin{array}{llllllllllll}\text { Straight } & 7 & 12 & 2 & - & 2 & 5 & 3 & 9 & 17 & 5 & - \\ \text { Curly } & 1 & 2 & 2 & 2 & - & 1 & - & 1 & 3 & 2 & 2\end{array}$

Backline:

$\begin{array}{cccccccccccc}\text { Straight } & 6 & 7 & 2 & 2 & 1 & 4 & 1 & 7 & 11 & 3 & 2 \\ \text { Swaybacked } & 2 & 7 & 2 & - & 1 & 2 & 2 & 3 & 9 & 4 & -\end{array}$

\section{Phenotypic Diversity}

The values of the Shannon- Weiner Diversity Index are generally falls between 1.5 and 3.5 only rarely it surpasses 4.5. A value near 4.6 indicates that the numbers of individuals are evenly distributed between all the species (Bibi and Ali, 2013). The Shannon- Weiner index increases as both the richness and the evenness of the community increases.

As shown on Table 16 it indicates that the equity of distribution in relation to hair type of boar has ED (5), sow (10) and gilt particularly in Tablas while in Sibuyan the ED were distributed to boar (1) sow (3) and gilt (2) whereas the phenotypic characteristics in relation to hair type of boar, sow and gilt were categorically have even distribution in terms of species richness and evenness which has diversity index ranging from 2.21 to 2.97 respectively which states that the hair of the species are homozygous in the province. These maybe attributed by traditional breeding practices of the local farmers using the same type of breed in mating their animal and the genetic material of the parents was inherited by the offspring. 
Table 16. The diversity index $(\mathrm{H})$ of hair type of native pigs in Romblon

\begin{tabular}{|c|c|c|c|c|}
\hline \multirow[t]{2}{*}{ Indicators } & \multicolumn{4}{|c|}{ Shannon Weiner Diversity Index } \\
\hline & Number in sample & Relative abundance "Pi" & LN "Pi" & $\mathrm{Pi} * \mathrm{LN}(\mathrm{Pi})$ \\
\hline \multicolumn{5}{|l|}{ Boar: } \\
\hline Curly & 1 & 0.10 & -2.302585093 & -0.230258509 \\
\hline Straight & 6 & 0.60 & -0.510825624 & -0.306495374 \\
\hline Short & 2 & 0.20 & -1.609437912 & -0.321887582 \\
\hline Dense & 1 & 0.10 & -2.302585093 & -0.230258509 \\
\hline \multirow[t]{3}{*}{ Total } & 10 & 1.00 & & -1.088899975 \\
\hline & & & & 1.088899975 \\
\hline & & & $\mathrm{H}^{\prime}=$ & 2.971004097 \\
\hline \multicolumn{5}{|l|}{ Sow: } \\
\hline Curly & 2 & 0.10 & -2.302585093 & -0.230258509 \\
\hline Straight & 13 & 0.65 & -0.430782916 & -0.280008895 \\
\hline Short & 3 & 0.15 & -1.897119985 & -0.284567998 \\
\hline Long & 2 & 0.10 & -2.302585093 & -0.230258509 \\
\hline \multirow[t]{3}{*}{ Total } & 20 & 1.00 & & -1.025093912 \\
\hline & & & & 1.025093912 \\
\hline & & & $\mathrm{H}^{\prime}=$ & 2.787357214 \\
\hline \multicolumn{5}{|l|}{ Gilt: } \\
\hline Curly & 1 & 0.142857143 & -1.945910149 & -0.277987164 \\
\hline Straight & 5 & 0.714285714 & -0.336472237 & -0.240337312 \\
\hline Short & 1 & 0.142857143 & -1.945910149 & -0.277987164 \\
\hline \multirow[t]{3}{*}{ Total } & 7 & 1.00 & & -0.79631164 \\
\hline & & & & 0.79631164 \\
\hline & & & $\mathrm{H}^{\prime}=$ & 2.217347452 \\
\hline
\end{tabular}

Tusks diversity index of tusks of native pigs was shown on Table 17 it was observed that there were no presence of tusks in boar, sow, gilt. It has a computed diversity index of 1 which means that it was no indication of such phenotypic characteristics. It was observed during the conduct of the study that the native pigs in Romblon has no presence of tusks. According to the respondents they have not observed that even old pigs do not have those traits they more even tell that their native pigs are not considered descendants of wild pigs.

Table 17. The diversity index $(\mathrm{H})$ of tusks of native pigs in Romblon

\begin{tabular}{|c|c|c|c|c|}
\hline \multirow[t]{2}{*}{ Indicators } & \multicolumn{4}{|c|}{ Shannon Weiner Diversity index } \\
\hline & $\begin{array}{l}\text { Number in } \\
\text { sample }\end{array}$ & Relative abundance "Pi" & LN "Pi" & $\mathrm{Pi} * \mathrm{LN}(\mathrm{Pi})$ \\
\hline \multicolumn{5}{|l|}{ Boar: } \\
\hline Present & 1 & 0.10 & -2.302585093 & -0.230258509 \\
\hline Absent & 9 & 0.90 & -0.105360516 & -0.094824464 \\
\hline \multirow[t]{3}{*}{ Total } & 10 & 1.00 & & -0.325082973 \\
\hline & & & & 0.325082973 \\
\hline & & & $\mathrm{H}^{\prime}=$ & 1.384145488 \\
\hline \multicolumn{5}{|l|}{ Sow: } \\
\hline Absent & 20 & 1.00 & 0 & 0 \\
\hline \multirow[t]{3}{*}{ Total } & 20 & 1.00 & & 0 \\
\hline & & & & 0 \\
\hline & & & $\mathrm{H}^{\prime}=$ & 1 \\
\hline \multicolumn{5}{|l|}{ Gilt: } \\
\hline Absent & 7 & 1.00 & 0 & 0 \\
\hline \multirow[t]{3}{*}{ Total } & 7 & 1.00 & & 0 \\
\hline & & & & 0 \\
\hline & & & $\mathrm{H}^{\prime}=$ & 1 \\
\hline
\end{tabular}


As shown in Table 18 indicates the Shannon - Weiner diversity index of snout of native pigs was computed with a range of 1.84 to 1.97 it means that it has the same type of characteristics. The evenness and richness were computed and ranging from 0.61 to 0.68 which also states that the distribution of the species in the province where categorically almost the same. There are no migration happening in the province because of the homogenous characteristics of species.

Table 18. The diversity index $(\mathrm{H})$ of snout of native pigs in Romblon

\begin{tabular}{|c|c|c|c|c|}
\hline \multirow[t]{2}{*}{ Indicators } & \multicolumn{4}{|c|}{ Shannon Weiner Diversity Index } \\
\hline & $\begin{array}{l}\text { Number in } \\
\text { sample }\end{array}$ & Relative abundance "Pi" & LN "Pi" & $\mathrm{Pi} * \mathrm{LN}(\mathrm{Pi})$ \\
\hline \multicolumn{5}{|l|}{ Boar: } \\
\hline Long and Thin & 7 & 0.70 & -0.356674944 & -0.249672461 \\
\hline Short \& & 3 & 0.30 & -1.203972804 & -0.361191841 \\
\hline \multicolumn{5}{|l|}{ Cylindrical } \\
\hline \multirow[t]{3}{*}{ Total } & 10 & 1.00 & & -0.610864302 \\
\hline & & & & 0.610864302 \\
\hline & & & $\mathrm{H}^{\prime}=$ & 1.842022775 \\
\hline \multicolumn{5}{|l|}{ Sow: } \\
\hline Long and Thin & 10 & 0.50 & -0.693147181 & -0.34657359 \\
\hline Short \& & 10 & 0.50 & -0.693147181 & -0.34657359 \\
\hline \multicolumn{5}{|l|}{ Cylindrical } \\
\hline \multirow[t]{3}{*}{ Total } & 20 & 1.00 & & -0.693147181 \\
\hline & & & & 0.693147181 \\
\hline & & & $\mathrm{H}^{\prime}=$ & 2 \\
\hline \multicolumn{5}{|l|}{ Gilt: } \\
\hline Long and Thin & 3 & 0.428571429 & -0.84729786 & -0.363127654 \\
\hline Short \& & 4 & 0.571428571 & -0.559615788 & -0.31978045 \\
\hline \multicolumn{5}{|l|}{ Cylindrical } \\
\hline \multirow[t]{3}{*}{ Total } & 7 & 1.00 & & -0.682908105 \\
\hline & & & & 0.682908105 \\
\hline & & & $\mathrm{H}^{\prime}=$ & 1.97962633 \\
\hline
\end{tabular}

The diversity index of coat color pattern of native pigs in the province of Romblon was shown in Table 19 it indicates that mostly there were plain color pattern of coat. Specie evenness was computed ranging from 0.32 to 0.94 which indicates also that coat color with in the province were categorically the same. However, when the body color is considered, the horizontal stripes are observed newborn piglets. Though it is not proved by the farmers in the locality that their piglets are descendant of wild pig the changes of body shape in these ancestral and descending populations could be attributed to directional selection of domestic population. Irrespective of the geographical separation respondents have not seen and observed what the characteristics of wild pigs is. Farmers cannot prove that there is a relationship between wild pig and their native pigs.

Table 19. The diversity index $(\mathrm{H})$ of coat color pattern of native pigs in Romblon

\begin{tabular}{lllll}
\hline \hline Indicators & \multicolumn{4}{l}{ Shannon Weiner Diversity Index } \\
& $\begin{array}{l}\text { Number } \\
\text { sample }\end{array}$ & in Relative abundance "Pi" & LN "Pi" & $\mathrm{Pi} *$ LN(Pi) \\
\hline Boar: & & & & \\
Plain & 9 & 0.90 & -0.105360516 & -0.094824464 \\
Spotted & 1 & 0.10 & -2.302585093 & -0.230258509 \\
Total & 10 & 1.00 & & -0.325082973 \\
& & & & 0.325082973
\end{tabular}


$\mathrm{H}^{\prime}=$

1.384145488

\begin{tabular}{lllll} 
Sow: & & & & 0 \\
Plain & 20 & 1 & & 0 \\
Total & 20 & 1 & $\mathrm{H}^{\prime}=$ & 0 \\
& & & & 1 \\
\hline Gilt: & & & -0.693147181 & -0.34657359 \\
Plain & 5 & 0.5 & -0.916290732 & -0.366516293 \\
Patchy & 4 & 0.4 & -2.302585093 & -0.230258509 \\
Spotted & 1 & 0.1 & & -0.943348392 \\
Total & 10 & 1 & $\mathrm{H}^{\prime}=$ & 0.943348392 \\
& & & & 2.568567607 \\
\hline \hline
\end{tabular}

Coat color type results shows that the Shannon- Weiner diversity index for coat color of boar, sow and gilt were $1.649384888,1.219590618$ and 3.170032825 respectively. This indicates homogenous groups on this traits. However, gilt of Sibuyan and Tablas had the same number (3) of equity distribution, while sow of Tablas had higher number of equity (14) than Sibuyan (7), boar of Tablas had equity distribution of (8) while Sibuyan had (2) of 2, Island in Romblon, boar and sow in Tablas had higher equitability of distribution (ED) than Sibuyan. It means that relatively greater numbers of boar and sow coat color type were evenly distributed (Table 20). The observed level of diversity may be due to same gene actions which does not interact and consequently expressed same color. The mechanisms of their distribution were probably due to dominance of such color within the group and selection preferences of their raisers.

Table 20. The diversity index $(\mathrm{H})$ of coat color type of native pigs in Romblon

\begin{tabular}{|c|c|c|c|c|}
\hline \multirow[t]{2}{*}{ Indicators } & \multicolumn{4}{|c|}{ Shannon Weiner Diversity Index } \\
\hline & $\begin{array}{l}\text { Number in } \\
\text { sample }\end{array}$ & Relative abundance "Pi" & LN "Pi" & $\mathrm{Pi} * \mathrm{LN}(\mathrm{Pi})$ \\
\hline \multicolumn{5}{|l|}{ Boar: } \\
\hline White & 2 & 0.2 & -1.609437912 & -0.321887582 \\
\hline Black & 8 & 0.8 & -0.223143551 & -0.178514841 \\
\hline \multirow[t]{2}{*}{ Total } & 10 & 1 & & $\begin{array}{l}-0.500402424 \\
0.500402424\end{array}$ \\
\hline & & & $\mathrm{H}^{\prime}=$ & 1.649384888 \\
\hline \multicolumn{5}{|l|}{ Sow: } \\
\hline Black & 19 & 0.95 & -0.051293294 & -0.04872863 \\
\hline Dark Red & 1 & 0.05 & -2.995732274 & -0.149786614 \\
\hline \multirow[t]{3}{*}{ Total } & 20 & 1 & & -0.198515243 \\
\hline & & & & 0.198515243 \\
\hline & & & $\mathrm{H}^{\prime}=$ & 1.219590618 \\
\hline \multicolumn{5}{|l|}{ Gilt: } \\
\hline White & 1 & 0.142857143 & -1.945910149 & -0.277987164 \\
\hline Black & 4 & 0.571428571 & -0.559615788 & -0.31978045 \\
\hline Dark Red & 1 & 0.142857143 & -1.945910149 & -0.277987164 \\
\hline Gray & 1 & 0.142857143 & -1.945910149 & -0.277987164 \\
\hline \multirow[t]{3}{*}{ Total } & 7 & 1 & & -1.153741943 \\
\hline & & & & 1.153741943 \\
\hline & & & $\mathrm{H}^{\prime}=$ & 3.170032825 \\
\hline
\end{tabular}


Results showed that the head shapes were homogenous 1.649384888-1.842022775 and 1.506993066 respectively (Table 21). The boar, sow and gilt were homogeneous for straight and long and thin head. Its ED was in the average of 8-2. Perhaps, the differences are in the number of sow to the number of gilt which has even number of distribution. In Tablas Island sow head shape were straight (13) while in Sibuyan (5) which is concave, it can be attributed to genes expressing this trait as a distinguishing feature for the group which they belong or living. In Sibuyan Island pig house were located near the coastline where in pigs can easily dump to take a bath. While in Tablas Island sow were located at the upland area where they need to struggle to dig hole for them to take a bath. These may attribute the head shape of the native pigs according to the location.

Table 21. The diversity index $(\mathrm{H})$ of head profile of native pigs in Romblon

\begin{tabular}{lllll}
\hline \hline Indicators & \multicolumn{3}{l}{ 'Shannon Weiner Diversity Index } & \\
\cline { 2 - 5 } & $\begin{array}{l}\text { Number in } \\
\text { sample }\end{array}$ & Relative abundance "Pi" & LN "Pi" & Pi * LN(Pi) \\
\hline Boar: & 2 & 0.2 & -1.609437912 & -0.321887582 \\
Concave & 8 & 0.8 & -0.223143551 & -0.178514841 \\
Straight & 10 & 1 & & -0.500402424 \\
Total & & & $\mathrm{H}^{\prime}=$ & 0.500402424 \\
& & & & 1.649384888 \\
\hline Sow: & & & -1.203972804 & -0.361191841 \\
Concave & 6 & 0.3 & -0.356674944 & -0.249672461 \\
Straight & 14 & 0.7 & & -0.610864302 \\
Total & 20 & 1 & $\mathrm{H}^{\prime}=$ & 0.610864302 \\
& & & & 1.842022775 \\
\hline Gilt: & & & -0.15415068 & -0.132129154 \\
Straight & 6 & 0.857142857 & -1.945910149 & -0.277987164 \\
Convex & 1 & 0.142857143 & & -0.410116318 \\
Total & 7 & 1 & $\mathrm{H}^{\prime}=$ & 0.410116318 \\
& & & & 1.506993066 \\
\hline \hline
\end{tabular}

Table 22 shows the Shannon- Weiner diversity index on the ear type of native pigs. Boar has computed index of 1.38, sow 1.98 and gilt 1.50 it states that the computation reveals the characteristics of the species in the community and has evenness of 0.32 for boar, sow 0.68 and gilt 0.41 respectively. The evenness of the ear type of native pigs in the province was also the same. These results indicate that droopy ear type were dominant among the native pigs in the province. Perhaps, these were the associated expressions of genes proven to be adaptable in local conditions and available resources.

Table 22. The diversity index $(\mathrm{H})$ of ear type of native pigs in Romblon

\begin{tabular}{lllll}
\hline \hline Indicators & \multicolumn{3}{l}{ Shannon Weiner Diversity Index } & \\
\cline { 2 - 5 } & $\begin{array}{l}\text { Number } \\
\text { sample }\end{array}$ & in Relative abundance "Pi" & LN "Pi" & Pi ${ }^{*}$ LN(Pi) \\
\hline Boar: & & & & \\
Droopy & 9 & 0.9 & -0.105360516 & -0.094824464 \\
Prick & 1 & 0.1 & -2.302585093 & -0.230258509 \\
Total & 10 & 1 & & -0.325082973 \\
& & & $\mathrm{H}^{\prime}=$ & 0.325082973 \\
& & & & 1.384145488 \\
\hline Sow: & 15 & 0.75 & -0.287682072 & -0.215761554 \\
Droopy & 1 & 0.05 & -2.995732274 & -0.149786614 \\
Semi-loop & 1 & & &
\end{tabular}




\begin{tabular}{lllll} 
Prick & 4 & 0.2 & -1.609437912 & -0.321887582 \\
Total & 20 & 1 & & -0.687435751 \\
& & & $\mathrm{H}^{\prime}=$ & 0.687435751 \\
& & & & 1.988609698 \\
\hline & & & \\
Gilt: & & 0.857142857 & -0.15415068 & -0.132129154 \\
Droopy & 6 & 0.142857143 & -1.945910149 & -0.277987164 \\
Loop & 1 & 1 & & -0.410116318 \\
Total & 7 & & $\mathrm{H}^{\prime}=$ & 0.410116318 \\
& & & & 1.506993066 \\
\hline \hline
\end{tabular}

The diversity index of ear orientation of native pigs in the province of Romblon Table 23 shows that the orientation of the ear was all projected forward. The native pigs in Romblon are evenly distributed. Diversity index for ear orientation pattern which is projected forward was somewhat higher than upward. The sow equity of distribution (15) with has diversity index of $\mathrm{H}^{\prime}=1.673058127$ had higher diversity than those of boar $H^{\prime}=1.384145488$ and gilt $\mathrm{H}^{\prime}=1.26338125$ respectively. The equitability of distribution ranged from $4-19$. Observed differences between the ear orientations may be due to the homogenous characteristics in relation to head phenotype.

Table 23. The diversity index $(\mathrm{H})$ of ear orientation of native pigs in Romblon

\begin{tabular}{|c|c|c|c|c|}
\hline \multirow{2}{*}{ Indicators } & \multicolumn{4}{|c|}{ Shannon Weiner Diversity Index } \\
\hline & $\begin{array}{l}\text { Number in } \\
\text { sample }\end{array}$ & Relative abundance "Pi" & LN "Pi" & $\mathrm{Pi} * \mathrm{LN}(\mathrm{Pi})$ \\
\hline $\begin{array}{l}\text { Boar: } \\
\text { Project } \\
\text { forward }\end{array}$ & 9 & 0.9 & -0.105360516 & -0.094824464 \\
\hline Upward & 1 & 0.1 & -2.302585093 & -0.230258509 \\
\hline Total & 10 & 1 & $\mathrm{H}^{\prime}=$ & $\begin{array}{l}-0.325082973 \\
0.325082973 \\
1384145488\end{array}$ \\
\hline $\begin{array}{l}\text { Sow: } \\
\text { Project } \\
\text { forward }\end{array}$ & 15 & 0.789473684 & -0.236388778 & -0.18662272 \\
\hline $\begin{array}{l}\text { Upward } \\
\text { Total }\end{array}$ & $\begin{array}{l}4 \\
19\end{array}$ & $\begin{array}{l}0.210526316 \\
1\end{array}$ & $\begin{array}{l}-1.558144618 \\
H^{\prime}=\end{array}$ & $\begin{array}{l}-0.328030446 \\
-0.514653165 \\
0.514653165 \\
1.673058127\end{array}$ \\
\hline $\begin{array}{l}\text { Gilt: } \\
\text { Project } \\
\text { forward }\end{array}$ & 15 & 0.9375 & -0.064538521 & -0.060504864 \\
\hline $\begin{array}{l}\text { Upward } \\
\text { Total }\end{array}$ & $\begin{array}{l}1 \\
16\end{array}$ & $\begin{array}{l}0.0625 \\
1\end{array}$ & -2.772588722 & $\begin{array}{l}-0.173286795 \\
-0.233791659 \\
0.233791659 \\
1.26338125\end{array}$ \\
\hline
\end{tabular}

Table 24 shows the diversity index of skin type of native pigs in the province of Romblon are all soft. Equity distribution was even in boar (10), while in sow (18) and gilt (6) as shown in Table 24. The diversity index resulted that boar has $\mathrm{H}^{\prime}=1$, sow $\mathrm{H}^{\prime}=1.384145488$ and gilt $\mathrm{H}^{\prime}=1.506993066$ it has an average of evenness which ranged from $0-0.410$; whereas, the $E \mathrm{D}$ ranges from $1-18$ respectively. 
Lower diversity index was due skin type and the greater magnitude of being concentrated to one color only. The observed diversities and distributions of skin type may be attributed to its dominance to the specific group.

Table 24. The diversity index $(\mathrm{H})$ of skin type of native pigs in Romblon

\begin{tabular}{|c|c|c|c|c|}
\hline \multirow[t]{2}{*}{ Indicators } & \multicolumn{4}{|c|}{ Shannon Weiner Diversity Index } \\
\hline & $\begin{array}{l}\text { Number in } \\
\text { sample }\end{array}$ & Relative abundance "Pi" & LN "Pi" & $\mathrm{Pi} * \mathrm{LN}(\mathrm{Pi})$ \\
\hline $\begin{array}{l}\text { Boar: } \\
\text { Smooth } \\
\text { Total }\end{array}$ & $\begin{array}{l}10 \\
10\end{array}$ & $\begin{array}{l}1 \\
1\end{array}$ & $\begin{array}{l}0 \\
\mathrm{H}^{\prime}=\end{array}$ & $\begin{array}{l}0 \\
0 \\
0 \\
1 \\
\end{array}$ \\
\hline $\begin{array}{l}\text { Sow: } \\
\text { Smooth } \\
\text { Wrinkled } \\
\text { Total }\end{array}$ & $\begin{array}{l}18 \\
2 \\
20\end{array}$ & $\begin{array}{l}0.9 \\
0.1 \\
1\end{array}$ & $\begin{array}{l}-0.105360516 \\
-2.302585093 \\
H^{\prime}=\end{array}$ & $\begin{array}{l}-0.094824464 \\
-0.230258509 \\
-0.325082973 \\
0.325082973 \\
1.384145488\end{array}$ \\
\hline $\begin{array}{l}\text { Gilt: } \\
\text { Smooth } \\
\text { Wrinkled } \\
\text { Total }\end{array}$ & $\begin{array}{l}6 \\
1 \\
7\end{array}$ & $\begin{array}{l}0.857142857 \\
0.142857143 \\
1\end{array}$ & $\begin{array}{l}-0.15415068 \\
-1.945910149 \\
H^{\prime}=\end{array}$ & $\begin{array}{l}-0.132129154 \\
-0.277987164 \\
-0.410116318 \\
0.410116318 \\
1.506993066\end{array}$ \\
\hline
\end{tabular}

As shown on Table 25 the diversity indexes of tail type of native pigs in the province of Romblon were categorically were all straight. The diversity index for tail type was closer to average of among the boar (1.38) and sow (1.52) than that of gilt (1.81). It was also found out that the ED of boar (9) and sow (17) were near to equal. These results indicate that occurrences and distributions of straight tail shapes were nearly equal. Expressions of body conformation can be attributed to accumulated expressions of genes in different body parts (Somes1990).

Table 25. The diversity index $(\mathrm{H})$ of tail type of native pigs in Romblon

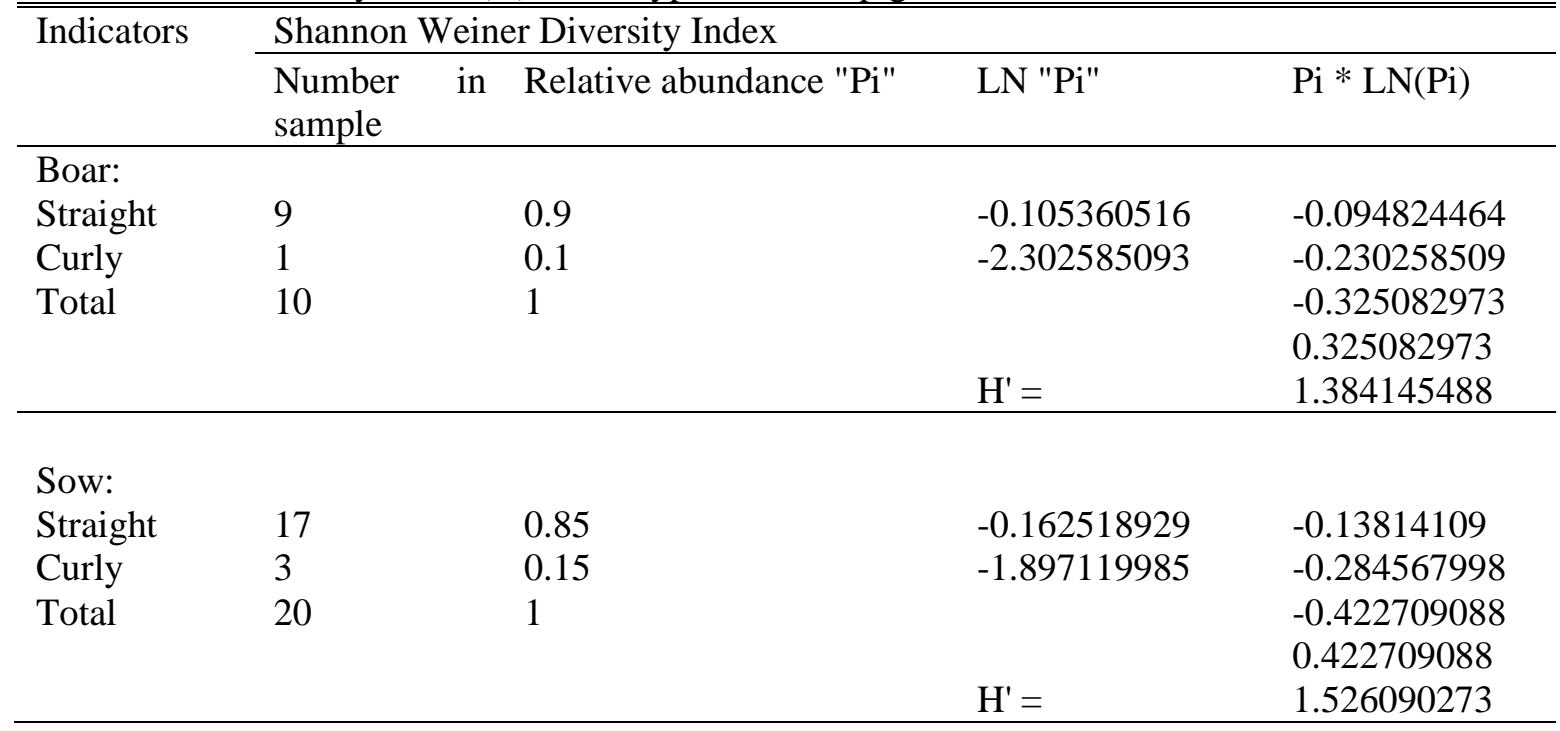




\begin{tabular}{lllll} 
Gilt: & & & & \\
Straight & 5 & 0.714285714 & -0.336472237 & -0.240337312 \\
Curly & 2 & 0.285714286 & -1.252762968 & -0.357932277 \\
Total & 7 & 1 & & -0.598269589 \\
& & & & 0.598269589 \\
& & & $\mathrm{H}^{\prime}=$ & 1.818968512 \\
\hline
\end{tabular}

Table 26 shows the diversity index of backline of native pigs in the province of Romblon. It was revealed in this table that the backline of boar, sow and gilts were measured with a range of 1.84 to 1.97 it shows that the index determines the evenness of the species which ranges from $0.61-0.68$ respectively . Phenotypic characteristics in relation to backline were almost the same which homozygous straight.

Table 26. The diversity index $(\mathrm{H})$ of backline of native pigs in Romblon

\begin{tabular}{|c|c|c|c|c|}
\hline \multirow[t]{2}{*}{ Indicators } & \multicolumn{4}{|c|}{ Shannon Weiner Diversity Index } \\
\hline & $\begin{array}{l}\text { Number in } \\
\text { sample (count) }\end{array}$ & $\begin{array}{l}\text { Relative } \\
\text { abundance "Pi" }\end{array}$ & LN "Pi" & $\mathrm{Pi} * \mathrm{LN}(\mathrm{Pi})$ \\
\hline \multicolumn{5}{|l|}{ Boar: } \\
\hline Straight & 7 & 0.7 & -0.356674944 & -0.249672461 \\
\hline Swayback & 3 & 0.3 & -1.203972804 & -0.361191841 \\
\hline \multirow[t]{3}{*}{ Total } & 10 & 1 & & -0.610864302 \\
\hline & & & & 0.610864302 \\
\hline & & & $\mathrm{H}^{\prime}=$ & 1.842022775 \\
\hline \multicolumn{5}{|l|}{ Sow: } \\
\hline Straight & 11 & 0.55 & -0.597837001 & -0.32881035 \\
\hline Swayback & 9 & 0.45 & -0.798507696 & -0.359328463 \\
\hline \multirow[t]{3}{*}{ Total } & 20 & 1 & & -0.688138814 \\
\hline & & & & 0.688138814 \\
\hline & & & $\mathrm{H}^{\prime}=$ & 1.990008308 \\
\hline \multicolumn{5}{|l|}{ Gilt: } \\
\hline Straight & 3 & 0.428571429 & -0.84729786 & -0.363127654 \\
\hline Swayback & 4 & 0.571428571 & -0.559615788 & -0.31978045 \\
\hline \multirow[t]{3}{*}{ Total } & 7 & 1 & & -0.682908105 \\
\hline & & & & 0.682908105 \\
\hline & & & $\mathrm{H}^{\prime}=$ & 1.97962633 \\
\hline
\end{tabular}

Morphometric characteristics

The analysis of variance presented on Table 27 on the morphometric characteristics of native pigs in the province of Romblon showed significant difference on the heart girth and mid girth of boar with a pvalue of .039 and .022 respectively. This means that, the heart girth $(83.06: 54.61 \mathrm{~cm})$ and mid girth (97.19:60.96cm) of boar in Tablas island is heavier than the boar in Sibuyan island as shown on the result of the circumferential width with a body weight of $49.58 \mathrm{~kg}$ and $20.25 \mathrm{~kg}$ respectively. However, the analysis of mean variance on the morphometric diversity of sow indicates that body weight, height, body length, ear width and ear length significantly differ between Tablas and Sibuyan Islands. The result states that, the body weight of sow $(74.03 \mathrm{~kg}$ ) in Sibuyan Island was heavier than the body weight of sow (54.29) in Tablas Island which is affected by the morphometric traits. 
The data on morphometric diversity of gilt presented on the table shows no significant difference observed between the gilt of the two islands. The result indicates that the gilt of the two islands have almost the same morphometric traits as indicated on the p-value.

Hence, the result of analysis on the morphometric characteristics of native pigs in the province of Romblon signifies that the observed differences was due to the feeding management of native pig raisers with regards to the manner of feeding in which according to the respondents they lack trainings/seminars on the proper feeding management. They fed the pigs based on their personal experience and old tradition.

Table 27. Morphometric characteristics of native pigs in the province of Romblon

\begin{tabular}{|c|c|c|c|c|c|}
\hline $\begin{array}{l}\text { Morphometric } \\
\text { Characteristics }\end{array}$ & $\begin{array}{l}\text { Tablas Island } \\
(\mathrm{N}=8)\end{array}$ & $\begin{array}{l}\text { Sibuyan Island } \\
\underline{\mathrm{N}=2)}\end{array}$ & F-test & & $\begin{array}{l}\text { Romblon } \\
\text { Province } \\
(\mathrm{N}=10)\end{array}$ \\
\hline & Mean & Mean & F value & $P$ value & Mean \\
\hline \multicolumn{6}{|l|}{ Boar: } \\
\hline Body weight $(\mathrm{kg})$ & 49.58 & 20.25 & 5.048 & $.055^{\mathrm{ns}}$ & 43.71 \\
\hline Height $(\mathrm{cm})$ & 62.07 & 44.45 & 2.447 & $.156^{\mathrm{ns}}$ & 58.55 \\
\hline Body length $(\mathrm{cm})$ & 88.42 & 62.23 & 4.442 & $.068^{\mathrm{ns}}$ & 83.19 \\
\hline Head length $(\mathrm{cm})$ & 26.26 & 24.13 & .183 & $.680^{\mathrm{ns}}$ & 25.83 \\
\hline Tail length $(\mathrm{cm})$ & 24.73 & 17.78 & 2.681 & $.140^{\mathrm{ns}}$ & 23.34 \\
\hline Heart girth $(\mathrm{cm})$ & 83.06 & 54.61 & 6.041 & .039 & 77.37 \\
\hline Mid girth (cm) & 97.19 & 60.96 & 8.051 & .022 & 89.94 \\
\hline Ear width $(\mathrm{cm})$ & 13.36 & 16.51 & .842 & $.386^{\mathrm{ns}}$ & 13.99 \\
\hline Ear length $(\mathrm{cm})$ & 29.21 & 16.51 & .366 & $.562^{\mathrm{ns}}$ & 26.67 \\
\hline Sow: & $\mathrm{N}=14$ & $\mathrm{~N}=7$ & & & $\mathrm{~N}=21$ \\
\hline Body weight $(\mathrm{kg})$ & 54.29 & 74.03 & 5.642 & .028 & 60.87 \\
\hline Height $(\mathrm{cm})$ & 60.05 & 70.76 & 5.653 & .028 & 63.62 \\
\hline Body length $(\mathrm{cm})$ & 92.18 & 121.19 & 12.885 & .002 & 101.85 \\
\hline Head length $(\mathrm{cm})$ & 28.28 & 27.21 & .636 & $.435^{\mathrm{ns}}$ & 27.93 \\
\hline Tail length $(\mathrm{cm})$ & 28.77 & 33.02 & .937 & $.345^{\mathrm{ns}}$ & 30.19 \\
\hline Heart girth $(\mathrm{cm})$ & 88.48 & 90.71 & .107 & $.747^{\mathrm{ns}}$ & 89.23 \\
\hline Mid girth $(\mathrm{cm})$ & 104.54 & 100.51 & .425 & $.522^{\mathrm{ns}}$ & 103.2 \\
\hline Ear width $(\mathrm{cm})$ & 15.53 & 18.51 & 5.708 & .027 & 16.52 \\
\hline Ear length $(\mathrm{cm})$ & 18.92 & 22.86 & 5.237 & .034 & 20.24 \\
\hline Gilt: & $\mathrm{N}=3$ & $\mathrm{~N}=3$ & & & $\mathrm{~N}=6$ \\
\hline Body weight $(\mathrm{kg})$ & 32.13 & 28.53 & 1.457 & $.294^{\mathrm{ns}}$ & 30.33 \\
\hline Height $(\mathrm{cm})$ & 51.22 & 49.11 & .610 & $.479^{\mathrm{ns}}$ & 50.17 \\
\hline Body length $(\mathrm{cm})$ & 70.61 & 71.54 & .017 & $.902^{\mathrm{ns}}$ & 71.08 \\
\hline Head length (cm) & 21.46 & 19.47 & .618 & $.476^{\mathrm{ns}}$ & 20.47 \\
\hline Tail length (cm) & 20.15 & 22.86 & 3.368 & $.140^{\mathrm{ns}}$ & 21.51 \\
\hline Heart girth $(\mathrm{cm})$ & 69.00 & 60.88 & 6.909 & $.058^{\mathrm{ns}}$ & 64.94 \\
\hline Mid girth $(\mathrm{cm})$ & 79.90 & 72.39 & 2.232 & $.210^{\mathrm{ns}}$ & 76.15 \\
\hline Ear width $(\mathrm{cm})$ & 13.41 & 9.82 & 4.350 & $.105^{\mathrm{ns}}$ & 11.62 \\
\hline Ear length $(\mathrm{cm})$ & 21.81 & 13.12 & 2.276 & $.206^{\mathrm{ns}}$ & 16.97 \\
\hline
\end{tabular}

$n s=$ not significant

Test of Relationship on the morphometric diversity and type of native pigs

Table 28 shows the relationship of morphometric diversity on the body weights of boar, sow and gilt in the province of Romblon. The data showed that the height, body length, head length, tail length, heart girth and mid-girth were significantly related at 0.05 level to the body weights of boar. This means that, 
the longer the length of the height, body, head, and tail as well as the wider the circumference of the heart girth and mid-girth the heavier the weights of boar.

On the other hand, the body weights of sow were significantly related at 0.01 and 0.05 level to the height, body length, tail length, heart girth, mid girth, ear width and ear length of sow. This means that the longer the height, the length of the body, tail, and ear as well as the wider the ear and the circumference of the heart girth and mid girth the heavier the weights of sow.

Likewise, the head length of gilt was significantly related at 0.05 level to the body weights which states that, the longer the length of the head the heavier the weights of the gilt.

Table 28. Relationship of morphometric dimensions to the body weight of native pigs in Romblon

\begin{tabular}{|c|c|c|c|}
\hline \multirow[t]{3}{*}{ Morphometric variable } & \multicolumn{3}{|c|}{ Body Weights } \\
\hline & Boar & Sow & Gilt \\
\hline & $\mathrm{N}=10$ & $\mathrm{~N}=21$ & $N=6$ \\
\hline \multirow[t]{2}{*}{ Height, $\mathrm{cm}$} & $0.874^{* *}$ & $0.676^{* *}$ & 0.574 \\
\hline & 0.001 & 0.001 & $0.233^{\mathrm{ns}}$ \\
\hline \multirow[t]{2}{*}{ Body length, $\mathrm{cm}$} & $0.970^{* *}$ & $0.907^{* *}$ & 0.692 \\
\hline & 0.000 & 0.000 & $0.128^{\mathrm{ns}}$ \\
\hline \multirow[t]{2}{*}{ Head length, $\mathrm{cm}$} & $0.834^{* *}$ & 0.413 & $0.838^{*}$ \\
\hline & 0.003 & $0.063^{\text {ns }}$ & 0.037 \\
\hline \multirow[t]{2}{*}{ Tail length, $\mathrm{cm}$} & $0.857^{* *}$ & $0.517^{*}$ & -0.319 \\
\hline & 0.002 & 0.016 & $0.538^{\mathrm{ns}}$ \\
\hline \multirow[t]{2}{*}{ Heart girth, cm } & $0.968^{* *}$ & $0.804^{* *}$ & 0.536 \\
\hline & 0.000 & 0.000 & $0.273^{\text {ns }}$ \\
\hline \multirow[t]{2}{*}{ Mid girth, $\mathrm{cm}$} & $0.957^{* *}$ & $0.660^{* *}$ & 0.594 \\
\hline & 0.000 & 0.001 & $0.214^{\mathrm{ns}}$ \\
\hline \multirow[t]{2}{*}{ Ear width, cm } & 0.104 & $0.677^{* *}$ & 0.728 \\
\hline & $0.776^{\text {ns }}$ & 0.001 & $0.101^{\mathrm{ns}}$ \\
\hline \multirow[t]{2}{*}{ Ear length, cm } & 0.055 & $0.485^{*}$ & 0.790 \\
\hline & $0.880^{\mathrm{ns}}$ & 0.026 & $0.062^{\mathrm{ns}}$ \\
\hline
\end{tabular}

**. Correlation is significant at the 0.01 level (2-tailed)

*. Correlation is significant at the 0.05 level (2-tailed

ns=not significant

Note: 0.874 r-value $\quad 0.001 p$-value

Bodyweight estimation of native pigs in Romblon

Based on the regression analysis the following equations were established for the estimation of the live body weight of native pigs in Romblon.

- Boar: $\mathrm{BW}=-44.84+0.559 \mathrm{BL}+0.544 \mathrm{HG}$

$$
\mathrm{R}^{2}=98.85 \%
$$

- Sow: $\mathrm{BW}=-59.37+0.6098 \mathrm{BL}+0.6515 \mathrm{HG}$

$\mathrm{R}^{2}=99.07 \%$

- Gilt: $\quad \mathrm{BW}=-32.51+0.4233 \mathrm{BL}+0.5043 \mathrm{HG}$

$$
\mathrm{R}^{2}=99.53 \%
$$

Where: $\mathrm{BW}=$ Body weight in kilograms

$\mathrm{BL}=$ Body length in centimeters

$\mathrm{HG}=$ Hearth girth circumference in centimeters

Equity of distribution

It was presented on Table 29 the equity of distribution of native pigs found in the province of Romblon. The data shows that in Tablas island, a total of 8 boars comes from the Municipality of Sta. Fe (1), Odiongan (5), and Looc (2); 14 sows were located at Sta. Fe (5), none in Sta. Maria, Odiongan (6), San Andres (1) and Looc (2); 3 gilts were located from Sta. Maria (1) and Looc (2); the 12 male piglets were 
found in Sta Fe. (3), Odiongan (4) and Looc (5); and the 10 female piglets were found in Sta Fe. (5), Odiongan (3), and Looc (2). Whereas in Sibuyan island a total of 2 boars found in the Municipality of Magdiwang (1) and San Fernado (1); 7 sows were found in Magdiwang (1), and Cajidiocan (5) and San Fernando (1); a total of 3 gilts were found in Magdiwang (2), and Cajidiocan (1); and no piglets found in the island. It only shows that the native pigs in the province of Romblon is critical and needs to be addressed by the provincial government and the concern government agency.

Table 29. Equity of distribution of native pigs found in the Province of Romblon

\begin{tabular}{|c|c|c|c|c|c|}
\hline \multirow[t]{3}{*}{ Location } & \multicolumn{5}{|c|}{ Kinds of Native Pigs } \\
\hline & \multirow{2}{*}{ Boar } & \multirow[t]{2}{*}{ Sow } & \multirow[t]{2}{*}{ Gilt } & \multicolumn{2}{|c|}{ Piglet } \\
\hline & & & & Male & Female \\
\hline \multicolumn{6}{|l|}{ Tablas island: } \\
\hline Sta. Fe & 1 & 5 & 0 & 3 & 5 \\
\hline Sta. Maria & 0 & 0 & 1 & 0 & 0 \\
\hline Odiongan & 5 & 6 & 0 & 4 & 3 \\
\hline San Andres & 0 & 1 & 0 & 0 & 0 \\
\hline Looc & 2 & 2 & 2 & 5 & 2 \\
\hline Sub-total & 8 & 14 & 3 & 12 & 10 \\
\hline \multicolumn{6}{|l|}{ Sibuyan island: } \\
\hline Magdiwang & 1 & 1 & 2 & 0 & 0 \\
\hline Cajidiocan & 0 & 5 & 1 & 0 & 0 \\
\hline San Fernando & 1 & 1 & 0 & 0 & 0 \\
\hline Sub-total & 2 & 7 & 3 & 0 & 0 \\
\hline TOTAL & 10 & 21 & 6 & 12 & 10 \\
\hline
\end{tabular}

Population Structure

It was presented on Table 30 the population structure and the effective population size of native pigs found in the province of Romblon. The data shows that the effective population who contribute offspring for the next generation were 7 boars consists one old boar and 6 young boars in the herd use as sire for mating. The population sizes of sows in the herd were 18 with possibility to become a dam to be mated to the sire. It was observed in the data that there were 5 pregnant sows and 6 gilts in herd.

According to Mace-Lande (1990), categorization has to be flexible in terms of data required. It is also need to be flexible in terms of population unit to which it applies. The categories made by MaceLande are categorized into: critical-50\% probability of extinction within 5 years or two generations, whichever is longer; endangered-20\% probability of extinction within 20 years or 10 generation whichever is longer; vulnerable-10\% probability of extinction within 100 years. These definitions were based on a consideration of theory of extinction times for single population as well as meaningful times scale for conservation action.

Therefore, the data show that the effective population structure of native pigs in the province of Romblon were categorically in critical stage which needs a thorough conservation and preservation.

Table 30. Population structure and the effective population size of native pigs in Romblon

\begin{tabular}{lll}
\hline \hline Native Pig Category & $\underline{\text { Sex }}$ & Female \\
\hline Piglet & Male & 3 \\
Boar & 20 & \\
Sow & 7 & 27 \\
Gilt & & 6 \\
\hline Total & 27 & 36 \\
\hline \hline
\end{tabular}


Formula for effective population size:

$$
\begin{aligned}
\mathrm{Ne}=\quad & \underline{4 \times \mathrm{Nm} \times \mathrm{Nf}} \\
& =4 \times 27 \times 36 /(27+36) \\
& =3888 / 63 \\
& =61.71
\end{aligned}
$$

Categorized into: critical-50\% probability of extinction within 5 years or two generations, whichever is longer according to Mace-Lande category.

\section{Findings}

This study was conducted to evaluate the phenotypic characterization and performance improvement of native pigs in the province of Romblon. It identifies the phenotypic characterization, morphometric diversity, and effective population size of native pigs. The study both used the scientific and nonscientific sampling method. The questionnaire was the instrument used to gather data needed to the study.

The data gathered were statistically analyzed using frequency/percentage and mean.

1.The phenotypic characteristics of native pigs in the province of Romblon found out that majority of the snout were long and thin; the head profile were straight; most of the ear type was droopy; the ear orientation were projected forward; have straight hair; the coat color pattern were plain; the coat color was black; the skin were smooth; the tail were straight and the backline was straight except for gilt which is swaybacked.

2. The Shannon Weiner Diversity Index on the phenotypic characteristics of native pigs in the province of Romblon was observed evenly distributed.

3.The morphometric characteristics of native pigs in the province of Romblon found out that significant difference was observe on the heart girth and mid-girth of boar; there were observe significant difference on the body weight, height, body length, ear width, and ear length of sow; while significant difference was failed to observed on the morphometric traits of gilt.

4. The test of relationship on the morphometric diversity and type of native pigs found out that significant relationship exists between the body weights and the height, body length, body length, head length, tail length, heart girth and mid-girth of boar; the height, body length, tail length, heart girth, midgirth, ear width, and ear length were significantly related to the body weights of sow; and the head length was significantly related to the body weights of gilt.

5. The equity of distribution of native pigs in the province of Romblon found out that there were 10 boars, 21 sows, 6 gilts, 12 male piglets and 10 female piglets. The effective population size that contribute offspring for the next generation were 7 boars use as sire for mating and 18 sows which has the possibility to become a dam.

\section{Conclusion}

There is significant difference and relationship on the body weights of boar and sow with regards to their morphometric traits.

\section{References}

[1] E. Subalini, G.L.L.P. Silva and C.M.B. Demetawewa. Phenotypic Characterization and Production Performance of Village Pigs in Sri Lanka Tropical Agricultural Research Vol. 21(2): 198 - 208.

[2] FAO. The Global Plan of Action for Animal Genetic Resources and the Interlaken Declaration. Rome, 2007.

[3] FAO. The State of the World's Animal Genetic Resources for Food and Agriculture, edited by B. Rischkowsky \& D. Pilling. Rome, 2007.

[4] FAO. The State of the World's Animal Genetic Resources for Food and Agriculture. FAO, Rome, 2007. 
[4] FAO. Report of the FAO/WAAP Workshop on Production Environment Descriptors for Animal Genetics Resources, 2009.

[5] FAO. Molecular Genetic Characterization of Animal Genetic Resources, 2011.

[6] FAO. Animal Production and Health Guidelines. No. 9. Rome.

[7] FAO. Phenotypic Characterization of Animal Genetic Resources. FAO Animal Production and Health Guidelines No.11. Rome, 2012.

[8] FAO. The Second Report on the State of the World's Animal Genetic Resources for Food and Agriculture. Rome, 2015.

[9] G. L. Gannad. Performance of weanling pigs fed with plant or animal protein in the starter ration. BS. Thesis. Benguet State University, La Trinidad Benguet. Pp. 1-3.

[10] B. Göhl. Tropical Feeds: Feed Information Summeries and Nutritive Values. FAO. Animal Production and Health Series No. 12 Rome, 1981

[11] Kwanchai A. Gomez and Arturo A. Gomez Statistical Procedure for Agricultural Research 2nd Edition. Published by Wiley and Sons Inc., 1984.

[12] H.W. Gonyou, W.R. Stricklin. Effects of floor area allowance and group size on the productivity of growing/finishing pigs, J. Anim. Sci. 76, 1326-1330.

[13] L.A. Goonewardena, P. Sahaayaruban, R. Rajamahendran and A.S.B. Rajaguru. Study of some production traits among indigenous pigs in Sri Lanka and its crosses with improved white breeds. WorldRev. of Animal Product. 20(2): 45-49.

[14] D.R. Notter. The importance of genetic diversity in livestock population of the future. J. Anim. Sci. 77, 61-69.

[15] O.G. Omitogun. Analysis of swine genome orga- nization. Evaluation of G-T-G bands in porcine chromo- somes for physical mapping. In: Ariyo, O.J., Ikeobi, C.O.N., Omoniyi, T. and Kehinde, O.B., Eds., Proceed-ings of the 29th Annual Conference of Genetics Society of Nigeria, 54-57.

[16] S. Pan S, S.K. Misra and M.S. Kundu. Ghoongroo pig: A new found animal genetic resource of sub- Himalayan West Bengal, India. Animal Genetic Resources In- formation, 37: 91-96.

[17] S.F. Sulabo. Philippines Univ. Los Baños, College, Laguna (Philippines). Animal and Dairy Sciences Cluster. Animal genetic resources: status of the existing swine multiplier herd populations under smallholder production in Laguna and Romblon, Region 4 Philippines, 2009.

[18] M. Toro, J. Ferna'ndez \& A. Caballero. Molecular characterization of breeds and its use in conservation. Livestock Science.doi:10.1016/j.livsci.2008.07.003 